\title{
NUNO RAMOS
}

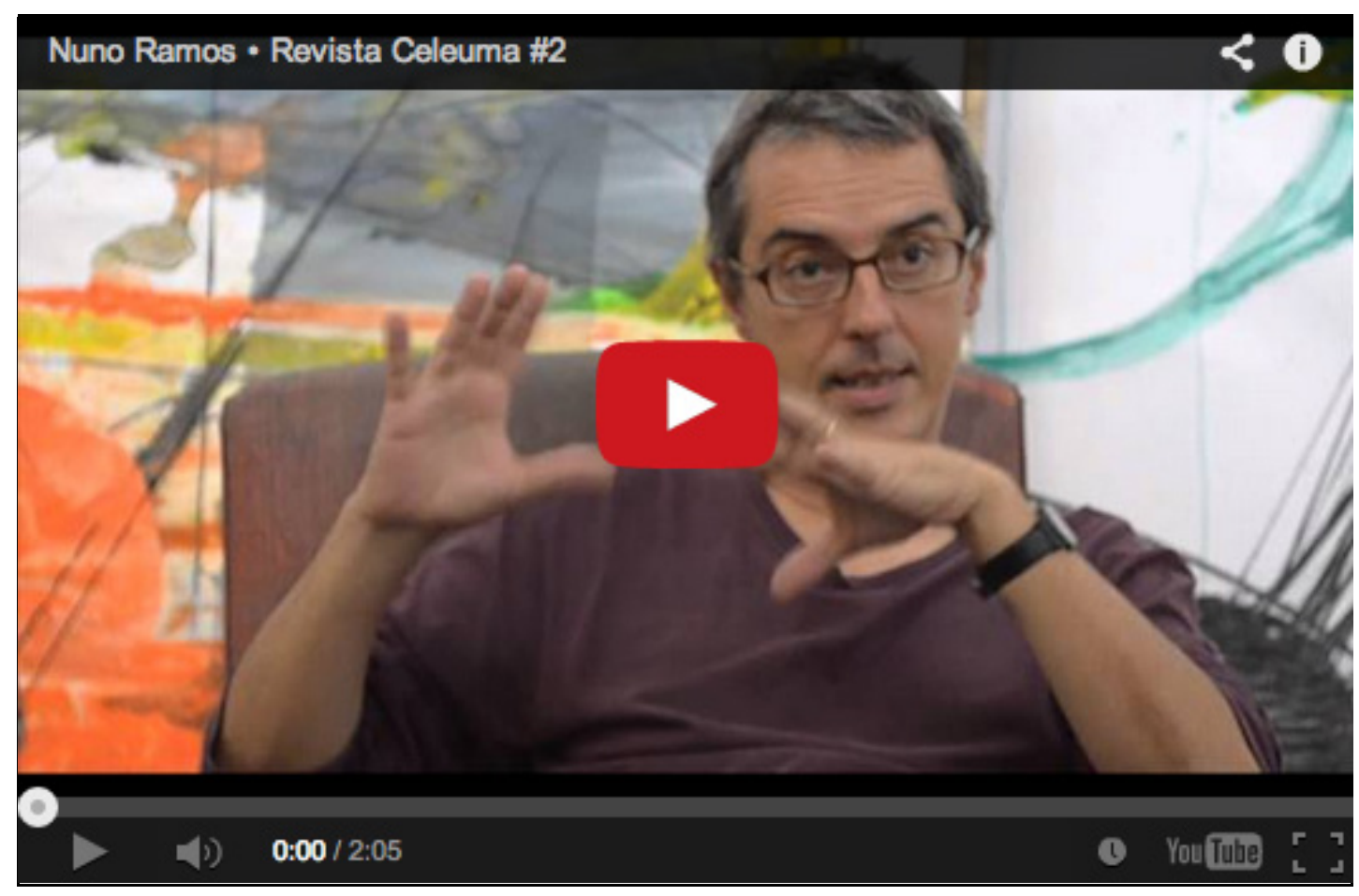

